\title{
CORPORATE GOVERNANCE AND FIRM PERFORMANCE IN THE OIL AND GAS INDUSTRY OF RUSSIA
}

\section{DOI: 10.17261/Pressacademia.2015414537}

\author{
Nurlan Orazalin ${ }^{1}$, Rashid Makarov ${ }^{2}$, Madina Ospanova ${ }^{3}$ \\ ${ }^{1}$ KIMEP University, e-mail: orazalin@kimep.kz \\ ${ }^{2}$ KIMEP University, e-mail: rashidm@kimep.kz \\ ${ }^{3}$ KIMEP University, e-mail: madina.osp@gmail.com
}

$\begin{array}{ll}\text { Keywords } & \text { ABSTRACT } \\ \begin{array}{l}\text { Corporate } \\ \text { Governance, } \\ \text { firm performance, } \\ \text { Russia, Oil and Gas } \\ \text { Industry }\end{array} \quad \begin{array}{l}\text { This study explores corporate governance practices in Russian oil and gas } \\ \text { companies over the 2009-2012 periods and examines the relationship } \\ \text { mechanisms. Our findings suggest that managerial ownership and foreign } \\ \text { ownership are positively associated with firm performance. Similarly, the } \\ \text { results on government ownership also support our initial hypothesis and } \\ \text { indicate that government ownership positively affects accounting }\end{array} \\ \begin{array}{l}\text { performance. However, our findings suggest that board size and } \\ \text { independent directors on the board do not appear to affect firm }\end{array} \\ \text { performance. This study demonstrates that corporate governance } \\ \text { practices implemented in developed markets have some relevance and } \\ \text { S10, G30, M10 }\end{array}$

\section{INTRODUCTION}

In recent years, corporate governance issues have received increased attention among scholars, practitioners and regulators worldwide (Jackling and Johl, 2009; Sami et al., 2011; Bozec and Bozec, 2011). For example, Brown et al (2011) report that their electronic search through Google Scholar provided approximately 287,000 results using 'corporate governance' as keywords in 2010. Hannifa and Hudaib (2006), Bhagat and Bolton (2008), Brown et al. (2011) also note that a wide range of accounting and finance studies have contributed to governance literature examining the relation between corporate governance and firm performance. Most prior studies document that effective corporate governance practices positively affect firm performance (Kiel and Nicholson, 2003; Haniffa and Hudaib, 2006; Jackling and Johl, 2009). However, another strand of governance literature concludes that corporate governance is negatively associated with performance (Yermak, 1996; Hutchinson and Gul, 2003; Mashayekhi and Bazaz, 2008). Interestingly, another strand of literature reports no association between corporate governance and firm performance (Bhagat and Black, 2008). Based on the existing research problem, this study focuses on the Russian market analyzing the relation between corporate governance practices of oil and gas companies and their operating performance. Therefore, the 
objective of this study is to explore corporate governance practices in Russia and investigate the association between governance structures and firm performance in oil and gas industry.

Russia has significantly improved its performance in recent years (KPMG, 2011). The country has reached the best results in different sectors of economy. Primarily this applies to the mining industry. Specifically, the oil and gas sector plays an important role in the economic growth of Russia. Furthermore, a large number of oil and gas companies such as Gazprom and Lukoil are located in Russia. This study attempts to contribute to the existing literature by exploring governance practices in the oil and gas industry of Russia, and examining the association between corporate governance and firm performance. In particular, we focus on the effects of individual corporate governance variables, namely board of directors, independent directors, management, foreign and government ownership characteristics, and auditing company.

The remainder of the paper is divided into six sections. The next section discusses the development of corporate governance and the Code of Corporate Governance in Russia. Section 3 reviews the relevant literature and also sets out the hypotheses for testing. Section 4 describes the data, variables and the research methodology, which is followed by a discussion of the results in the next section. Finally, the summary and conclusions are presented in Section 6.

\section{CORPORATE GOVERNANCE IN RUSSIA}

Russia for the first time has faced with the concept of corporate governance at the end of the twentieth century. The main reasons of its development were increased interest to the corporate governance in USA and others countries in 1980's and the world financial crisis of 1997-1998 and corporate problems in emerging countries (Румянцев, 2010).

The first step toward improving corporate governance in Russia was the adoption of the Principles of Corporate Governance in 1999 by the organization for economic cooperation and development (Румянцев, 2010). By that time, these principles were the first set of standards and guidelines in the fields of corporate governance. Later, this document was replaced by the Code of Corporate Governance. The Code of Corporate Governance (hereinafter Code) is a set of the rules, which are designed for securities market participants. In the Russian Federation, Code of corporate governance has been recommended by Federal Financial Markets Service (formerly the Federal Commission for Securities Markets) with the participation and support of the representatives of the Western business community, domestic issuers and professional participants of the securities market on April 4, 2002 (http://www.ecgi.org). Earlier, in November 2001, the Code was approved at a meeting of the Russian Government. Before the economic crisis of 2008, Russian system of corporate governance was flexible and not completely formed (KPMG, 2011). Because of this, the system has undergone a lot of changes. Before the 2008, many companies mostly formally complied with the basic requirements of the law and other corporate governance standards dictated by the existing codes, and other requirements of regulators, stock exchanges, and etc. In a sense, there was a mechanical adherence to the rules, which was to ensure the effective management of the company in 
terms of application mechanisms of corporate governance. This confidence among companies was supported by the investment attractiveness factor, expressed in the growth rate of shares of public companies. During the crisis, the corporate governance has ceased to be a tool of external investment attractiveness and companies shifted focus towards the development of corporate governance systems. Because of the economic crisis, owners of most public companies realized the necessity of improving the internal efficiency of their business processes (KPMG, 2011).

Economic and financial crisis has contributed to self-determination of the Russian model of corporate governance, which should not be imposed by legislation, but should be formed based on the experience of companies and then secured at the legislative level. Development and compliance with corporate governance standards in most of top Russian companies are assigned to a single person or a structure, and not distributed over various company departments within their direct action (Lazareva et al., 2007). Often this function is performed by the board of directors, directors of corporate governance and corporate secretaries.

After economic crisis of 2008, the Russian business community realized the importance of effective of corporate governance practices in achieving good results in strategic planning and risk management. One of the advantages of corporate governance in Russia is an appearance of independent directors on the board that is considered like a sign of a formal compliance with generally accepted standards. Analysis of corporate governance practices shows that one of its major problems is the contradiction between fixed procedures and actual decision-making processes. Management decisions are often not accepted in a comprehensive basis and implemented without the use of modern management techniques. The next significant weaknesses, which are noted by Румянцев (2010), are lack of transparency and low efficiency of monitoring over senior management activities.

\section{LITERATURE REVIEW AND HYPOTHESIS DEVELOPMENT}

\subsection{Board size and firm performance}

According to the resource dependency theory, a board of directors is an important governance mechanism that affects firm performance positively. Larger boards are more productive in the decision making process (Dalton et al., 1998), have more knowledge and skills (Van den Berghe and Levrau, 2004) and diversified (Pearce and Zahra, 1992; and Goodstein et al., 1994). Similarly, Henry (2008) reports statistically significant and positive relationship between board size and the Q-ratio. However, Haniffa and Hudaib (2006) conclude that large board is seen as less effective and could also be costly for companies. Based on the results of the majority of prior studies and the resource dependency theory, it is hypothesized that:

H1: There is a positive relationship between board size and firm performance. 


\subsection{Board composition and firm performance}

Agency theory states that the majority of independent directors on the board of directors leads to the agency cost reduction because it is easier to control managers' actions (Fama and Jensen, 1983). Weir et al. (2002), Ho and Williams (2003), and Gupta and Fields (2009) provide evidence that firms with high percentage of independent directors deliver higher performance. However, other studies argue that the percentage of independent directors is not associated with firm performance (e.g., Fosberg, 1989; Klein, 1998; Bhagat and Black, 2002). Based on the agency theory and the findings of most prior studies, it is hypothesized that:

H2: There is no relationship between the proportion of independent directors on the board and firm performance.

\subsection{Managerial ownership and firm performance}

There are two views on the management ownership issue. According to the agency theory, prevailing managerial ownership can be very risky, and it is not beneficial for a company (Beatty and Zajac, 1994). In contrast, if managers are also shareholders of the company, the majority of their actions tend to support company interests. Douma et al. (2006) find a positive relationship between performance and management ownership. Hence, our next hypothesis is:

H3: There is a positive relationship between the management ownership and firm performance.

\subsection{Foreign ownership and firm performance}

Barbosa and Louri (2005) conclude that foreign ownership has a positive impact on firm performance due to many reasons such as geographical expansion, product differentiation, and economies of scale. Foreign ownership also improves firm performance because it requires more corporate disclosure and transparency in financial reporting system of a company (Patibandla, 2006). To examine this relationship, our fourth hypothesis is:

H4: There is a positive relationship between the presence of the foreign shareholders and firm performance.

\subsection{Government ownership and firm performance}

Government ownership is another common feature of Russian business environment. State is interested in the economic growth; therefore here is a positive relation between government ownership and firm performance (Hart et al., 1997). Ang and Ding (2006) conclude that government linked companies show higher market valuation than nongovernment linked companies. Hence, our next hypothesis is: 
H5: There is a positive relationship between the presence of the government and firm performance.

\subsection{External auditors and firm performance}

External auditors play a significant role in corporate governance of a firm. Large audit firms are bigger targets for litigation, and hence, they attempt to be more conservative and more diligent, thereby meaning there is a greater association between higher audit quality and larger audit firms. The financial audit provides shareholders with transparent information on the current performance of the company. According to Ojo (2009), an improvement of corporate governance in Europe, in the aftermath of Enron, would require the involvement of intermediaries such as external auditors. Therefore, it is hypothesized:

H6: There is a positive relationship between the auditing company size and firm performance.

\section{DATA AND METHODOLOGY}

\subsection{Sample Selection}

The sample of this study includes 20 the biggest Russian companies in the oil and gas industry. The study focuses on the post crisis period between 2009 and 2012. The data for two companies are not available for 2009 and 2012 respectively; therefore, the full sample includes 78 observations for four years. Data research variables are mainly extracted from the annual reports and other recourses, which provide information on financial data and corporate governance variables.

\subsection{Description of Variables}

The dependent variable is a firm performance which represents accounting performance variables include including equity to assets ratio (proxy for capital adequacy measurement), asset growth (proxy for asset management measurement), sales to asset ratio (proxy for management measurement), return on assets and return on equity ratios (proxies for earnings measurement), current ratio and quick ratio (proxies for liquidity measurement). The independent variables consist of six corporate governance variables. They are board size, number of independent directors on the board, management ownership, foreign ownership, government ownership, and auditing company. Size and age are control variables. Description and measurement of research variables are presented in Table 1 . To analyze the relationship between the firm performance and individual corporate governance mechanisms, the following model is used:

PERFORMANCE $=\alpha 0+\beta 1 \mathrm{BSIZE}+\beta 2$ INDIR $+\beta 3$ MANOWN $+\beta 4$ FOROWN $+\beta 5$ GOVOWN + $\beta 6$ AUDIT $+\beta$ SSIZElog $+\beta 8$ AGE $+\varepsilon$,

where: 
PERFORMANCE - one of the alternative operating performance measures, BSIZE - board size, INDIR - the number of independent directors, MANOWN - managerial ownership, FOROWN - foreign ownership, GOVOWN - state ownership, AUDIT - the type of auditing company, AGE - company age, and SIZE - company size.

Table 1: Research Variables Definition/Measurement

\begin{tabular}{|c|c|c|}
\hline Variables & Acronym & Operationalization \\
\hline \multicolumn{3}{|l|}{ Dependent variables } \\
\hline \multicolumn{3}{|l|}{ Accounting performance } \\
\hline Capital Adequacy & CAPAD & $\begin{array}{l}\text { Equity to Assets ratio. This ratio is a proxy for } \\
\text { accounting measure of financial strength and } \\
\text { stability. } \\
\text { Asset growth is a proxy for firm growth. Total }\end{array}$ \\
\hline Asset Growth & GROWTH & $\begin{array}{l}\text { Assets of the current year minus Total Assets } \\
\text { of the previous year divided by Total Assets } \\
\text { of the previous year. }\end{array}$ \\
\hline Management & MNGT & $\begin{array}{l}\text { Sales to Asset ratio (also known as Asset } \\
\text { Turnover ratio). It shows the amount of sales } \\
\text { generated per dollar of assets. }\end{array}$ \\
\hline Return on Asset & ROA & Net Income divided by Total Assets \\
\hline Return on Equity & ROE & Net Income divided by Equity \\
\hline Current Assets Ratio & CA & $\begin{array}{l}\text { Current Assets divided by Current Liabilities. } \\
\text { Current Assets minus Inventory divided by }\end{array}$ \\
\hline Quick Ratio & QA & Current Liabilities. \\
\hline \multicolumn{3}{|l|}{ Independent variables } \\
\hline Board size & BSIZE & $\begin{array}{l}\text { Total number of directors on the board of the } \\
\text { company. }\end{array}$ \\
\hline Independent directors & INDIR & $\begin{array}{l}\text { Total number of the independent directors } \\
\text { on the board of the company. }\end{array}$ \\
\hline Management ownership (\%) & MANOWN & $\begin{array}{l}\text { The proportion of the shares owned by the } \\
\text { managers of the company. }\end{array}$ \\
\hline Foreign ownership (\%) & FOROWN & $\begin{array}{l}\text { The proportion of the shares owned by the } \\
\text { foreign shareholders of the company. }\end{array}$ \\
\hline Government ownership (\%) & GOVOWN & $\begin{array}{l}\text { The proportion of the shares owned by the } \\
\text { government. }\end{array}$ \\
\hline Auditing company & AUDIT & $\begin{array}{l}\text { Dichotomous with } 1 \text { if auditing company that } \\
\text { tests the observed company is one of the Big } \\
\text { Four and } 0 \text { otherwise. }\end{array}$ \\
\hline \multicolumn{3}{|l|}{ Control variables } \\
\hline Company size & SIZE log & Natural log of total Assets of the company. \\
\hline Company age & AGE & $\begin{array}{l}\text { Number of years since foundation of the } \\
\text { company. }\end{array}$ \\
\hline
\end{tabular}




\section{FINDINGS AND ANALYSIS}

Table 2 presents the summary statistics of the dependent, independent, and control variables based on 78 observations. Several observed companies had a negative growth during some years, therefore the minimum value for GROWTH is $-13 \%$. The mean values for ROA and ROE are $10.49 \%$ and $38.11 \%$ respectively. In terms of liquidity, the mean values of CA and QA are 5.88 and 5.63 times respectively.

Table 2: Descriptive Statistics

\begin{tabular}{|lrrrr|}
\hline & Minimum & Maximum & Mean & Std. Deviation \\
\hline CAPAD (\%) & 0.11 & 97.87 & 58.15 & 25.478 \\
GROWTH & -13.10 & 1448.11 & 46.31 & 174.51 \\
(\%) & & & & \\
MGMT & .00 & 7.01 & .8319 & 1.05994 \\
ROA (\%) & -2.15 & 71.21 & 10.49 & 9.816 \\
ROE (\%) & -12.01 & 983.11 & 38.11 & 117.16 \\
CA (times) & .45 & 225.73 & 5.8863 & 25.56747 \\
QA (times) & .34 & 225.48 & 5.6369 & 25.54811 \\
BSIZE & .00 & 15.00 & 7.9103 & 3.76307 \\
IND & .00 & 7.00 & 2.2051 & 2.25837 \\
MANOWN & .00 & 1.75 & .0899 & .32382 \\
FOROWN & .00 & 100.00 & 7.5762 & 22.79623 \\
GOVOWN & .00 & 100.00 & 23.3670 & 36.31862 \\
AUDIT & .00 & 1.00 & .6923 & .46453 \\
SIZElog & 1.50 & 13.00 & 8.7244 & 2.43722 \\
AGE & 1.00 & 21.00 & 15.2436 & 4.31604 \\
\hline
\end{tabular}


Table 3. Pearson correlation. Up scripts * and ** indicate two-tailed significance levels of 0.05 and 0.01 respectively.

CAPAD GROWTH MGMT ROA ROE CA QA BSIZE INDIR MANOWN FOROWN GOVOWN AUDIT SIZElog AGE

\begin{tabular}{|c|c|c|c|c|c|c|c|c|c|c|c|c|c|c|c|}
\hline CAPAD & 1 & $-.282^{*}$ & $-.470^{* *}$ & $.233^{*}$ & $-.396^{* *}$ & $.270^{*}$ & $.265^{*}$ & .108 & .183 & .135 & $-.336^{* *}$ & $.395^{* *}$ & -.174 & .162 & $.477^{* *}$ \\
\hline GROWTH & $-.282^{*}$ & 1 & $.536^{* *}$ & .068 & $.273^{*}$ & -.030 & -.029 & -.157 & -.176 & -.023 & $.643^{* *}$ & -.041 & $-.246^{*}$ & $-.378^{* *}$ & $.525^{* *}$ \\
\hline MGMT & $-.470^{* *}$ & $.536^{* *}$ & 1 & -.049 & $.554^{* *}$ & -.093 & -.092 & -.118 & -.200 & -.100 & $.722^{* *}$ & -.211 & -.093 & $-.246^{*}$ & $.510^{* *}$ \\
\hline ROA & $.233^{*}$ & .068 & -.049 & 1 & .018 & .146 & .145 & -.037 & -.045 & .102 & -.131 & $.421^{* *}$ & $-.237^{*}$ & -.201 & .082 \\
\hline ROE & $-.396^{* *}$ & $.273^{*}$ & $.554^{* *}$ & .018 & 1 & -.032 & -.030 & -.166 & -.171 & -.041 & $.563^{* *}$ & -.078 & -.043 & $-.234^{*}$ & $.380^{* *}$ \\
\hline CA & $.270^{*}$ & -.030 & -.093 & .146 & -.032 & 1 & $1.000^{* *}$ & -.064 & -.041 & -.038 & -.059 & $.309^{* *}$ & $-.248^{*}$ & -.074 & .053 \\
\hline QA & $.265^{*}$ & -.029 & -.092 & .145 & -.030 & $1.000^{* *}$ & 1 & -.064 & -.042 & -.038 & -.058 & $.308^{* *}$ & $-.247^{*}$ & -.075 & .052 \\
\hline BSIZE & .108 & -.157 & -.118 & -.037 & -.166 & -.064 & -.064 & 1 & $.431^{* *}$ & .081 & -.096 & .076 & $.385^{* *}$ & $.612^{* *}$ & $.316^{* *}$ \\
\hline INDIR & .183 & -.176 & -.200 & -.045 & -.171 & -.041 & -.042 & $.431^{* *}$ & 1 & $.441^{* *}$ & -.208 & .177 & .110 & $.627^{* *}$ & $.322^{* *}$ \\
\hline MANOWN & .135 & -.023 & -.100 & .102 & -.041 & -.038 & -.038 & .081 & $.441^{* *}$ & 1 & -.093 & -.181 & .030 & .101 & $.229^{*}$ \\
\hline FOROWN & $-.336^{* *}$ & $.643^{* *}$ & $.722^{* *}$ & -.131 & $.563^{* *}$ & -.059 & -.058 & -.096 & -.208 & -.093 & 1 & -.132 & -.145 & $-.294^{* *}$ & $.635^{* *}$ \\
\hline GOVOWN & $.395^{* *}$ & -.041 & -.211 & $.421^{* *}$ & -.078 & $.309^{* *}$ & $.308^{* *}$ & .076 & .177 & -.181 & -.132 & 1 & -.184 & .107 & .157 \\
\hline AUDIT & -.174 & $-.246^{*}$ & -.093 & $-.237^{*}$ & -.043 & $-.248^{*}$ & $-.247^{*}$ & $.385^{* *}$ & .110 & .030 & -.145 & -.184 & 1 & $.517^{* *}$ & $.252^{*}$ \\
\hline SIZElog & .162 & $-.378^{* *}$ & $-.246^{*}$ & -.201 & $-.234^{*}$ & -.074 & -.075 & $.612^{* *}$ & $.627^{* *}$ & .101 & $-.294^{* *}$ & .107 & $.517^{* *}$ & 1 & $.544^{* *}$ \\
\hline AGE & $.477^{* *}$ & $-.525^{* *}$ & $-.510^{* *}$ & .082 & $-.380^{* *}$ & .053 & .052 & $.316^{* *}$ & $.322^{* *}$ & $.229^{*}$ & $-.635^{* *}$ & .157 & $.252^{*}$ & $.544^{* *}$ & 1 \\
\hline
\end{tabular}

Table 3 shows Pearson's correlation results for variables used in this research. Significant correlations among independent and control variables may potentially lead to multicollinearity problems. To test for presence of multicollinearity, we have checked variance inflation factors (VIF) for all variables in all the regression models and identified that maximum number is 2.297 (Age variable) which is far below of 5.00, thereby suggesting that no multicollinearity is present. The finding signals better performance with the presence of the government as a shareholder. As expected, auditing company is negatively associated with firm performance indicating more conservative reporting for companies audited by Big 4. The negative correlation of SIZE log with ROA supports the study of Weir et al. (2002), suggesting that smaller companies are better performers.

Table 4 shows the regression results for the effects of operating performance on governance practices and the control variables. Contrary to Hypotheses $\mathrm{H}_{1}$ and $\mathrm{H}_{2}$, BSIZE and INDIR are not associated with any of operating performance variables. Consistent with $\mathrm{H}_{3}$, management ownership has a significant and positive relationship with ROA. This 
result is contrary to Beatty and Zajac (1994), but supports Douma et al. (2006) that management ownership positively affects the company's earnings. The regression results for FOROWN indicate that there is a positive relationship between the presence of the foreign shareholders and operating performance. This is consistent with the findings of Barbosa and Louri (2005) and Patibandla (2006). With regard to government ownership, the empirical results show that there is a positive and significant association between GOVOWN and performance variables including CAPAD, ROA, CA, and QA. Finally, AUDIT is negatively associated with CAPAD, CA, and QA. This indicates that companies audited by Big 4 disclose more conservative financial reports which result in much more conservative operating performance indicators. Overall, the empirical findings indicate that corporate governance practices including managerial ownership, foreign ownership, and government ownership had a positive impact on operating performance variables in the post-crisis period.

Table 4. Regression Analysis. Upscripts *, **, and *** indicate significance of $0.10,0.05$, and 0.01 respectively.

\begin{tabular}{|c|c|c|c|c|c|c|c|}
\hline & CAPAD & GROWTH & MGMT & ROA & ROE & CA & QA \\
\hline \multirow[t]{2}{*}{ (Constant) } & .213 & 1.958 & .905 & .157 & .500 & 2.723 & 2.600 \\
\hline & $(1.627)^{*}$ & $(2.332)^{* *}$ & $(1.902)^{* *}$ & $(2.971)^{* * *}$ & $(.793)$ & $(.174)$ & (.167) \\
\hline \multirow[t]{2}{*}{ BSIZE } & .004 & .021 & -.010 & .004 & -.039 & .055 & .060 \\
\hline & (.489) & (.407) & $(-.342)$ & (1.291) & $(-.990)$ & $(.056)$ & $(.061)$ \\
\hline \multirow[t]{2}{*}{ INDIR } & -.086 & .356 & .028 & -.059 & .097 & -19.148 & -18.915 \\
\hline & $(-.524)$ & $(.340)$ & $(.048)$ & $(-.901)$ & (.123) & $(-.983)$ & $(-.971)$ \\
\hline \multirow[t]{2}{*}{ MANOWN } & .097 & .323 & -.162 & .075 & .077 & 6.410 & 6.384 \\
\hline & (1.027) & $(.532)$ & $(-.471)$ & $(1.956)^{* *}$ & (.169) & $(.569)$ & $(.566)$ \\
\hline \multirow[t]{2}{*}{ FOROWN } & -.001 & .040 & .031 & -.001 & .029 & -.043 & -.041 \\
\hline & $(-.447)$ & $(4.554) * * *$ & $(6.203)^{* * *}$ & $(-1.034)$ & $(4.335)^{* * *}$ & $(-.260)$ & $(-.248)$ \\
\hline \multirow[t]{2}{*}{ GOVOWN } & .002 & .003 & -.004 & .001 & .001 & .205 & .204 \\
\hline & $(2.914)^{* * *}$ & $(.596)$ & $(-1.352)$ & $(4.306)^{* * *}$ & $(.332)$ & $(2.353)^{* *}$ & $(2.345)^{* *}$ \\
\hline \multirow[t]{2}{*}{ AUDIT } & -.142 & -.171 & .004 & -.015 & .336 & -13.279 & -13.103 \\
\hline & $(-2.143)^{* *}$ & $(-.400)$ & $(.015)$ & $(-.546)$ & $(1.050)$ & $(-1.674)^{*}$ & $(-1.651)^{*}$ \\
\hline \multirow[t]{2}{*}{ SIZE log } & .002 & -.149 & .006 & -.013 & -.041 & .971 & .923 \\
\hline & $(.083)$ & $(-1.204)$ & $(.088)$ & $(-1.635)^{*}$ & $(-.444)$ & (.423) & (.402) \\
\hline \multirow[t]{2}{*}{ AGE } & .025 & -.048 & -.013 & .001 & .003 & .184 & .190 \\
\hline & $(2.929)^{* * *}$ & $(-.855)$ & $(-.401)$ & (.324) & $(.068)$ & $(.178)$ & (.183) \\
\hline Adj. R-square & $33 \%$ & $41 \%$ & $48.8 \%$ & $25.1 \%$ & $26.4 \%$ & $5.2 \%$ & $5.1 \%$ \\
\hline F-stat & 5.742 & 7.701 & 10.167 & 4.220 & 4.444 & 1.533 & 1.514 \\
\hline
\end{tabular}




\section{CONCLUSION}

This study explores corporate governance practices in Russian oil and gas companies in the post-crisis period and examines the relationship between accounting performance measures and corporate governance mechanisms. The results indicate that the board size and independent directors on the board do not appear to affect firm performance. This result supports Fosberg (1989), Bhagat and Black (2002), Klein (1998) who find no linkage between number of independent directors and firm performance. Moreover, our results indicate that management ownership has a positive impact company performance. This implies that managerial ownership increases earnings and therefore improves the performance of oil and gas companies in Russia. The findings on foreign ownership suggest that foreign ownership is positively associated with firm performance. The empirical evidence shows that foreign owners were able to improve asset growth, management quality and liquidity. The results on government ownership also support our initial hypothesis and indicate that better government ownership positively affects accounting performance. One of the features of Russian corporate governance is a government involvement in the business process (Lazareva et al., 2007). The analysis confirmed that the government as a stakeholder is a prosperous mechanism of corporate governance of the Russian companies in the oil and gas industry.

The study indicates that companies audited by Big 4 issue more conservative financial reports which result in much more conservative accounting performance indicators. The control variables like firm size and age have significant relationships with firm performance. For example, size is negatively associated performance thereby suggesting that small companies on average outperform large firms. We acknowledge several limitations of this research that suggest further investigation of the topic. Firstly, only six independent variables were tested in this study. It is possible to consider other variables such as the presence of different committees, CEO duality, CEO education, etc. Secondly, sample size is relatively small due to a small number of companies and only four years included in this study. One of possible directions for future research can be to extend time period and conduct a comparative analysis of the pre-crisis and post-crisis periods. Third, this study considers Oil and Gas industry only. Further and deeper insights can result from a comparative study conducted on inter-industry dataset. And finally, this study tests the correlation of corporate governance indices only with accounting performance variables. Therefore, considering market performance, for example, using Tobin's $Q$ ratio can highlight other aspects of the governance - performance relations. 


\section{REFERENCES}

Ang, J. and Ding, D. (2006), 'Government ownership and the performance of governmentlinked companies: The case of Singapore', Journal of Multinational Financial Management, Vol. 16, No. 1, pp. 64-88.

Barbosa, N. and Louri H. (2005), "Corporate Performance: Does Ownership Matter? A Comparison of Foreign- and Domestic-Owned Firms in Greece and Portugal", Review of Industrial Organization, Springer, Vol. 27(1), pp. 73-102.

Beatty, R.P. and Zajac, E.J. (1994), “Managerial Incentives, Monitoring and Risk Bearing: A Study of Executive Compensation, Ownership and Board Structure in Initial Public Offerings", Administrative Science Quarterly, 3 (2), pp. 313- 335.

Bhagat, S. and Black, B. (2002), "The non-correlation between board independence and long-term firm performance”, Journal of Corporation Law, 27, pp. 231-274.

Bhagat, S. and Bolton, B. (2008), "Corporate Governance and Firm Performance”, Journal of Corporate Finance, Vol. 14, pp.257-273.

Bozec, R. and Bozec, Y. (2011), "The Use of Governance Indexes in the GovernancePerformance Relationship Literature: International Evidence", Canadian Journal of Administrative Sciences, Revue canadienne des sciences de l'administration, Vol. 29, pp.79-98

Brown, P., Beekes, W., and Verhoeven, P. (2011), "Corporate governance, accounting and finance: A review". Accounting and Finance, Vol. 51, pp. 96-172.

Dalton, D.R., Daily, C. M., Ellstrand, A. E. and Johnson, J. L. (1998), “Meta-analytic Reviews of Board Composition, Leadership Structure and Financial Performance", Strategic Management Journal, 19, pp. 269-290.

Donaldson, L. and Davis, J. H. (1994), "Boards and Company Performance - Research Challenges the Conventional Wisdom", Corporate Governance: An International Review, 2(3), pp. 151-160.

Douma, S., George, R. and Kabir, R. (2006), "Foreign and Domestic ownership, Business groups, and Firm performance: evidence from a large emerging market", Strategic Management Journal, 27, pp. 637-657.

Fama, E.F. and Jensen, M.C. (1983), "Separation of Ownership and Control", Journal of Law and Economics, Vol.26, pp. 301-326. 
Fosberg, R. H. (1989), “Outside Directors and Managerial Monitoring”, Akron Business and Economic Review, 20, pp. 24-32.

Goodstein, J., Gautum, K. and Boeker, W. (1994), "The Effect of Board Size and Diversity on Strategic Change", Strategic Management Journal, Vol. 15, pp. 241-291.

Gupta, M. and Fields, L. (2009), 'Board independence and corporate governance: Evidence from director resignations', Business Finance and Accounting, 36(2), pp.161-184.

Haniffa, R. and Hudaib, M. (2006), “Corporate Governance Structure and Performance of Malaysian Listed Companies", Journal of Business Finance and Accounting, 33(7) and (8), pp. 1034-1062.

Hart, O., Shleifer, A. andVishny, M.W. (1997), "The proper Scope of Government: Theory and an Application to Prisons", The Quarterly Journal of Economics, 112(4), pp. 11271161.

Henry, D. (2008), 'Corporate Governance Structure and the Valuation of Australian Firms: Is there Value in Ticking the Boxes', Business Finance and Accounting, 35(8), pp.912-942.

Ho, C. and Williams, S. (2003), 'International Comparative Analysis of the Association between Board Structure and the Efficiency of Value Added by a Firm from its Physical Capital and Intellectual Capital Resources', the International Journal of Accounting, 38(4), pp.465-491.

Hutchinson, M. and Gul, F.A. (2003), "Investment Opportunity Set, Corporate Governance Practices and Firm Performance”, Journal of Corporate Finance, Vol. 10, pp. 595-614.

Jackling, B. and Johl, S. (2009), "Board Structure and Firm Performance: Evidence from India's Top Companies", Corporate Governance: An International Review, 17(4), pp. 492509.

Kiel, G.C. and Nicholson, G.J. (2003), "Board Composition and Corporate Performance: how the Australian Experience Informs Contrasting Theories of Corporate Governance", Blackwell Publishing, Vol. 11(3).

Klein, A. (1998), "Firm Performance and Board Committee Structure", Journal of Law and Economics, Vol. 41, pp 275-303.

KPMG (2011), “Практики корпоративного управления в России: определение границ национальной модели”, Экспертно-аналитический доклад.

Krivogorsky, V. (2006), "Ownership, board structure, and performance in continental Europe", International Journal of Accounting, 41, pp. 176-197. 
Lazareva, O., Rachinsky, A. andStepanov., S. (2007), "A Survey of Corporate Governance in Russia", Centre for Economic and Financial Research at New Economic School, No 103.

Mashayekhi, B. and Bazaz, M.S. (2008), "Corporate Governance and Firm Performance in Iran", Journal of Contemporary Accounting and Economies, Vol. 4, No 2, pp. 156-172.

Ojo, M. (2009), "The role of external auditors in corporate governance: agency problems and the management of risk", MPRA Paper, No. 28149, available at http://mpra.ub.unimuenchen.de/28149

Patibandla, M. (2006), "Equity Pattern, Corporate Governance and Performance: A Study of India's corporate sector", Journal of Economic Behavior and Organization, Vol. 59, pp. 29-44.

Pearce, J.H. and Zahra, S.A. (1992), "Board Composition from a Strategic Contingency Perspective", Journal of Management Studies, Vol. 29, pp. 411-449.

Sami, H., Wang, J., and Zhou, H. (2011), "Corporate governance and operating performance of Chinese listed firms", Journal of International Accounting, Auditing and Taxation, Vol. 20, pp.106-114.

Van den Berghe, L.A.A. and Levrau, A. (2004), "Evaluating boards of directors: What constitutes a good corporate board?", Corporate Governance: An International Review, 12, pp. 461-478.

Weir, C. and Laing, D. (1999), "The Governance-Performance Relationship: The Effects of Cadbury Compliance on UK Quoted Companies", European Accounting Conference, Bordeaux.

Weir, C., Laing, D. and McKnight, P. (2002), 'Internal and External Governance Mechanisms: Their Impact on the Performance of Large UK Public Companies', Business Finance and Accounting, 29(5), pp.579-611.

Yermack, D. (1996), "Higher Market Valuation of Companies with a Small Board of Directors", Journal of Financial Economics, Vol. 40, pp. 185-211.

"The Russia Corporate Governance Manual", 2004, International Finance Corporation from http://www.ita.doc.gov/goodgovernance/CorpGovManual.asp

Румянцев, И.С. (2010), “Особенности Корпоративного Управления в России в Трансформируемой Экономике”, Вестник Челябинского Государственного Университета, №5 (186), рр. 130-134. 